\title{
BIJI BUAH BISBUL (Diospyros blancoi) SEBAGAI BIOSORBEN Cr(III)
}

\author{
Nina Ariesta*, Rifansyah, Dian Arrisujaya dan Mamay Maslahat \\ Program Studi Kimia, Fakultas MIPA, Universitas Nusa Bangsa Bogor \\ Jl. KH. Sholeh Iskandar Km.4 Tanah Sareal Bogor, 16166 \\ *e-mail: ariestanina14@gmail.com
}

\section{ABSTRACT \\ Velvet Apple Fruit Seeds (Diospyros blancoi) as Biosorbent of Cr(III)}

\begin{abstract}
Velvet Apple Fruit (Diospyros blancoi) has not been explored more in Indonesia. The purpose of research was to explore the use of Velvet Apple Fruit seeds as adsobent of $\mathrm{Cr}(\mathrm{III})$ in waste. Biosorbent of velvet apple fruit seeds in removing $\mathrm{Cr}$ (III) metal ions has been investigated using batch method. Several parameters were used to determine absorption optimum conditions such as solution $\mathrm{pH}$, contact time and biosorbent dosage. Langmuir, Freundlich and Temkin isotherm models were used in determining biosorption equilibrium. FTIR and SEM-EDX were used to characterize the velvet apple fruit seeds biosorbent. The equilibrium adsorption isotherms showed the velvet apple fruit seeds biosorbent had a maximum adsorption capacity of $5.592 \mathrm{mg} / \mathrm{g}$. The adsorption efficiency of $\mathrm{Cr}$ (III) ion by velvet apple fruit seeds was $81.78 \%$. The results showed that velvet apple fruit seeds potentially as an alternative low-cost biosorbent for removing heavy metal ions in solution.
\end{abstract}

Keywords: biosorption, heavy metals, alternative biosorbent, waste water treatment

\begin{abstract}
ABSTRAK
Buah bisbul di Indonesia belum tereksplor dengan baik potensinya. Tujuan penelitian adalah untuk megetahui potensi biji buah Bisbul sebagai adsorben logam $\mathrm{Cr}$ (III) pada limbah. Biosorben biji buah bisbul (Diospyros blancoi) dalam menyerap ion logam $\mathrm{Cr}$ (III) telah diteliti dengan menggunakan metode batch. Beberapa parameter digunakan untuk menentukan kondisi optimum penyerapan seperti $\mathrm{pH}$ larutan, waktu kontak dan dosis biosorben. Model isoterm Langmuir, Freundlich dan Temkin dipakai dalam menentukan kesetimbangan biosorpsi. FTIR dan SEM-EDX digunakan dalam mengkarakterisasi biosorben biji buah bisbul. Isoterm adsorpsi kesetimbangan menunjukkan biosorben biji buah bisbul mempunyai kapasitas adsorpsi maksimum 5,592 mg/g. Efisiensi penyerapan ion $\mathrm{Cr}$ (III) oleh biji buah bisbul mencapai $81,78 \%$. Hasil penelitian menunjukkan bahwa biji buah bisbul berpotensi sebagai alternatif biosorben murah dalam menghilangkan ion logam berat dalam larutan.
\end{abstract}

Kata kunci: biosorpsi, logam berat, alternatif biosorben, pengolahan air limbah

\section{PENDAHULUAN}

Limbah yang mengandung logam berat memiliki dampak yang berbahaya bagi kehidupan manusia. Logam berat yang sering terkandung dalam limbah salah satunya adalah logam $\mathrm{Cr}$ (Krom). Logam kromium murni tidak ditemukan di alam. Logam ini ditemukan dalam bentuk senyawa padat atau mineral dengan unsur-unsur lain. Krom tahan korosi sehingga digunakan sebagai pelapis elektrolit. Senyawa krom seperti kromat dan dikromat banyak digunakan oleh industri tekstil, pencelupan, fotografi dan zat warna (Palar, 1994). Baku mutu limbah tekstil untuk logam krom total adalah $1 \mathrm{mg} / \mathrm{L}$ menurut PP menteri Lingkungan Hidup tahun 2010.Logam krom memiliki dua bilangan oksidasi, yaitu Cr(III) dan $\mathrm{Cr}(\mathrm{VI})$. Logam $\mathrm{Cr}(\mathrm{VI})$ dapat meracuni tubuh dan menyebabkan kematian pada konsentrasi $4,1 \mathrm{mg} / \mathrm{kg}$ berat tubuh manusia, sedangkan logam $\mathrm{Cr}$ (III) tidak memiliki pengaruh yang berbahaya bagi tubuh (Guertin, 2014).

Salah satu metode untuk mengurangi kadar logam Krom dalam limbah adalah adsorpsi dengan menggunakan adsorben. Adsorpsi ini banyak terjadi pada adsorben dari karbon teraktivasi, seperti karbon teraktivasi dari kulit padi dapat digunakan untuk adsorben pada bahan bakar (Cheenmatchaya \& Kungwankunakon, 2014), karbon teraktivasi dari enceng gondok untuk adsorpsi zat warna (Kanawade \& Gaikwad, 2011), dan karbon teraktivasi dari batang tumbuhan sengkaten (Shendkar et al, 2013). Adsorben 
dari kulit telur untuk menyerap pewarna tekstil (malachite green) (Podstawczyk, Witek-Krowiak, Chojnacka, \& Sadowski, 2014).

Beberapa tahun terakhir ini telah dikembangkan material penyerap logam berat berbasis biomaterial antara lain hasil buangan pertanian seperti daun jagung (Babarinde, Babalola, \& Sanni 2007), biomassa seperti alga (Beolchini et al., 2005; Jafari et al., 2012 dan Yalcin, Sezer \& Apak, 2012), ragi, bakteri (Vieira dan Volesky, 2000; Nagase et al., 2005; Ranjan, Srivastava, Talat, Hasan, 2009), lumut (Acar, Ozvatan,\& Ilim, 2005), jamur (Preetha dan Virutaghiri, 2005), asam alginat, selulosa, chitosan (Prakash, Sudha, \& Renganathan., 2011), tin (Gupta, Pathania, Agarwal, \& Sharma., 2012), Sukun (Linda, Lim, Priyantha, Tennakoon, \& Dahri, 2012), kembang sepatu (Vankar, Sarswat \& Sahu, 2011) serta kulit manggis (Zein, Suhaili, Earnestly, Indrawati, \& Munaf, 2010) dan yang berbasiskan geomaterial seperti tanah liat dan perlit (Dyer, Tangkawanit, \& Rangsriwatananon, 2004; dan Prakash, Latha, Sudha, \& Renganathan, 2012). Material-material ini terdapat dalam jumlah yang banyak dan murah.

Kandungan gugus karboksil $(-\mathrm{C}=\mathrm{O})$, amino (-NH), dan hidroksil $(-\mathrm{OH})$ membuat bahan alam dapat dimanfaatkan sebagai adsorben (Edokpayi, 2015). Penyerapan ion $\mathrm{Cr}(\mathrm{VI})$ oleh adsorben dari rumput laut (Fucus vesiculosus) dibuktikan dengan analisis FT-IR terdapat gugus hidroksil ($\mathrm{OH})$ dan gugus amino yang berkurang setelah adsorbsi yang menyebabkan ion $\mathrm{Cr}(\mathrm{VI})$ terikat pada permukaan adsorben (Cobas, Saronman, \& Pazos, 2014). Salah satu pemanfaatan limbah biomassa dijadikan sebagai adsorben adalah adsorben dari cangkang Arenga pinnata merr untuk logam $\mathrm{Cr}$ (III) dan $\mathrm{Cr}(\mathrm{VI})$ (Zein, Arrisujaya, Hidayat, Elfia, Nazarudin, \& Munaf., 2014), Adsorben dari limbah sekam dan jerami padi (Naiya, Singha, \& Das, 2011; Singha, Naiya, Bhattacharya, \& Das, 2011; Kumar, Arya, Singh, \& Vats, 2017), akar eceng gondok (Singha et al., 2011); tempurung kelapa (Singha et al., 2011), kulit kayu pohon mangga, batu bata, batu kapur, bubuk biji pepaya dan Alga (Gandhi, Sirisha, \& Sekhar, 2013) dapat dimanfaatkan untuk mengurangi cemaran ion logam $\mathrm{Cr}(\mathrm{VI})$, adsorben dari biji alpukat untuk logam $\mathrm{Cu}(\mathrm{II}), \mathrm{Pb}$ (II) dan $\mathrm{Cd}(\mathrm{II})$ (Wanja, Murungi, Wanjau \& Hassanali, 2015).

Buah Bisbul (Diospyros blancoi) merupakan buah lokal yang berkembang di wilayah Bogor. Nama lain buah bisbul adalah buah mentega atau buah mabolo. Tanaman bisbul bebuah sepanjang tahun, jarak antara bunga dan buah selama empat bulan. Pada umumnya, buah tersebut banyak dimanfaatkan untuk dimakan dengan mengambil daging buahnya. Daging buah bisbul diekstrak untuk diambil zat aktifnya, dimanfaatkan sebagai zat antioksidan dan zat antidiare (Howlader, Rahman, Khalipa, Ahmed, \& Rahman, 2012), analgesik (Akter, Majunder, Karim, Ferdous, \& Sikder, 2015a), dan antiinflamasi (Ragasa, 2009). Pengamatan awal buah bisbul memiliki biji dalam satu buahnya terdapat 3-8 biji dengan ukuran sekitar 3-5 cm. Penelitian tentang pemanfaatan biji buah bisbul masih sedikit. Pemanfaatan yang telah dilakukan adalah sebagai zat antimikroba (Akter \& Sarker, 2015b). Pada umumnya, setiap biji tersusun atas kandungan lignin dan selulosa. Hal tersebut menyebabkan biji buah bisbul berpotensi dimanfaatkan sebagai adsorben. Pemanfaatan biji buah bisbul perlu dilakukan aktivasi untuk meningkatkan potensinya sebagai adsorben. Potensi tersebut dapat ditentukan dari kapasitas penyerapannya. Model interaksi adosorbsi $\mathrm{Cr}$ (III) juga perlu diteliti untuk mengetahui prosesnya. Sehingga, perlu dilakukan penelitian tentang potensi adsorben dari biji buah bisbul untuk mengadsorpsi ion logam Cr(III).

\section{BAHAN DAN METODE}

\section{Bahan dan Alat}

Bahan-bahan yang digunakan dalam penelitian ini yaitu, Biji Buah Bisbul / Diospyros blancoi (diambil di daerah pasar Bogor, Bogor, Jawa Barat), $\mathrm{Cr}\left(\mathrm{NO}_{3}\right)_{3}$ (Merck), $\mathrm{K}_{2} \mathrm{Cr}_{2} \mathrm{O}_{7}$ (Merck), $\mathrm{HNO}_{3} 65 \%$ (Merck), $\mathrm{NaOH}$ (Merck), etanol, kertas saring dan akuades. Peralatan yang digunakan dalam penelitian ini meliputi 
peralatan sederhana dan instrumen. Peralatan sederhana yang digunakan yaitu seperangkat alat gelas, botol semprot, grinder, neraca digital, oven, dan magnetic stirer.

\section{Metode}

\section{Preparasi Biji Buah Bisbul}

Biji Buah Bisbul yang diambil di Pasar Bogor dibersihkan dari kotoran yang menempel, kemudian dicuci dengan air bersih dan dijemur di udara terbuka. Setelah kering kemudian dihaluskan dengan cara ditumbuk dengan alu dan diayak dengan ayakan berdasarkan ukuran partikel yang akan dipakai 100 mesh. Biji Buah Bisbul dengan ukuran tersebut direndam dalam larutan $\mathrm{HNO}_{3}$ 0,1 $\mathrm{M}$ selama 2 jam sambil sesekali diaduk. Hasil rendaman disaring kemudian dicuci dengan aquades. Setelah itu direndam dengan etanol selama 2 jam, kemudian dikeringkan kembali.

\section{Karakterisasi Biosorben}

Struktur dan interaksi-interaksi pada biosorben dipantau menggunakan spektrometer Fourier transform infrared (FTIR). Morfologi permukaan biosorben diamati dengan menggunakan spektrometer scanning electron microscopy with energy dispersive X-ray (SEM-EDX). Konsentrasi Krom diukur menggunakan spektrometer serapan atom (SSA).

\section{Metode Batch Adsorpsi}

Metode batch digunakan dalam menentukan kondisi optimum biosorben dalam menyerap ion Krom dalam laturan yaitu pengaruh $\mathrm{pH}$ larutan, waktu kontak, dosis biosorben dan konsentrasi Krom (Zein, 2014). Penyerapan ion logam krom sebanyak $25 \mathrm{~mL}$ oleh biosorben biji buah bisbul dilakukan menggunakan alat magnetic stirrer dengan kecepatan pengadukan $125 \mathrm{rpm}$. Setelah proses kesetimbangan, biosorben biji buah bisbul disaring dari larutan menggunakan penyaring Whatman, dan filtratnya dianalisis kadar logamnya.

Efisiensi penyerapan (R\%) ion logam krom oleh biosorben biji buah bisbul dihitung menggunakan persamaan (1).

$$
\mathrm{R} \%=\frac{C i-C e}{C i} \times 100 \%
$$

Di mana, $\mathrm{Ci}$ dan $\mathrm{Ce}$ merupakan konsentrasi awal dan konsentrasi saat setimbang dalam $\mathrm{mg} / \mathrm{L}$.

Kapasitas penyerapan (Qe) ion logam di mana jumlah total logam krom yang terserap (mg) per unit massa biosorben (g), ditentukan dengan menggunakan persamaan (2).

$$
\mathrm{Qe}=\frac{C i-C e}{m} \times V
$$

dimana, $m$ adalah massa biosorben dalam gram, dan $V$ merupakan jumlah volume larutan dalam liter.

\section{Isoterm Adsorpsi}

Kajian isoterm adsorpsi dilakukan untuk menggambarkan penyerapan ion logam oleh biosorben. Tiga model isoterm yang dikaji adalah persamaan isoterm Langmuir, Freundlich, dan Temkin. Persamaan isoterm linier dijabarkan sebagai berikut:

$$
\begin{aligned}
& \text { Langmuir: } \\
& \frac{1}{\mathrm{Qe}}=\left\{\frac{1}{\mathrm{~K}_{\mathrm{L}} \mathrm{Qm}}\right\} \frac{1}{\mathrm{Ce}}+\frac{1}{\mathrm{Qm}} \\
& \text { Freundlich: } \\
& \log Q e=\log K_{f}+\frac{1}{n} \log C e \\
& \text { Temkin: } \\
& Q e=A+B \ln C e
\end{aligned}
$$

Dimana, Ce merupakan konsentrasi $\mathrm{Cr}$ pada saat kesetimbangan (mgL-1), Qe adalah milligram ion logam terserap per gram biosorben (mg g-1); dan $\mathrm{K}_{\mathrm{L}}$ dan $\mathrm{Qm}$ merupakan konstanta Langmuir yang masing-masing adalah konstanta kesetimbangan dan kapasitas serapan maksimum. $\mathrm{K}_{\mathrm{f}}$ dan $1 / \mathrm{n}$ merupakan konstanta Freundlich sedangkan A dan B merupakan konstanta Temkin.

\section{HASIL DAN PEMBAHASAN}

\section{Karakterisasi Biosorben Biji Buah Bisbul}

\section{FTIR}

Rendemen adsorben yang dihasilkan dari proses aktivasi dengan asam nitrat $0,1 \mathrm{M}$ adalah 63\%. Adsorben teraktivasi selanjutnya diuji dengan spektrofotometer FTIR. Hasil interpretasi terhadap spektrum 
inframerah biji buah bisbul sebelum dan sesudah penyerapan terdapat puncak serapan $3550-3300 \mathrm{~cm}^{-1}$ yang menunjukkan adanya gugus hidroksil. Pada daerah 3300-3000 $\mathrm{cm}^{-}$ 1 terdapat penyerapan yang menunjukkan adanya regangan $\mathrm{C}-\mathrm{H}$ aromatic, didukung dengan adanya serapan pada daerah 1650 $1500 \mathrm{~cm}^{-1}$ yang merupakan spektrum pendukung identifikasi senyawa aromatik, puncak serapan juga ditunjukkan pada daerah 850-650 $\mathrm{cm}^{-1}$ yang merupakan regangan $\mathrm{Ar}-\mathrm{H}$. Terdapat pula serapan pada 1800-1650 $\mathrm{cm}^{-1}$ yang menandakan keberadaan karbonil aldehida atau keton. Gugus $\mathrm{O}-\mathrm{H}$ yang diperoleh dapat diidentifikasi sebagai senyawa polisakarida seperti selulosa yaitu $1170-1150 \mathrm{~cm}^{-1}, 1050$ $\mathrm{cm}^{-1}$ dan $1030 \mathrm{~cm}^{-1}$. Terdapat senyawa aromatik yang kemungkinan besar menunjukkan adanya senyawa lignin karena terdapat puncak serapan pendukung yang khas dari lignin yaitu $1590 \mathrm{~cm}^{-1}$ dan 1510 $\mathrm{cm}^{-1}$ (Stuart, 2004).

Perubahan dalam intensitas dan pergeseran puncak-puncak bisa diamati dari spektrum FTIR setelah terjadinya penyerapan oleh biosorben biji buah bisbul ditunjukkan pada Gambar 2. Peningkatan intensitas di semua puncak menunjukkan keterlibatan gugus $\mathrm{O}-\mathrm{H}, \mathrm{C}-\mathrm{H}$ dan $\mathrm{C}-\mathrm{O}$ dalam proses adsorpsi (Andrade, Rollemberg, \& Nobrega, 2005). Dari hasil yang ditunjukkan pada Gambar 2, jelas bahwa gugus fungsi ini memperoleh muatan positif ketika terprotonasi dan dapat berinteraksi dengan kompleks logam bermuatan negatif. Pergeseran ini juga terlihat sama dengan hasil yang dilaporkan Zein et al., (2014)

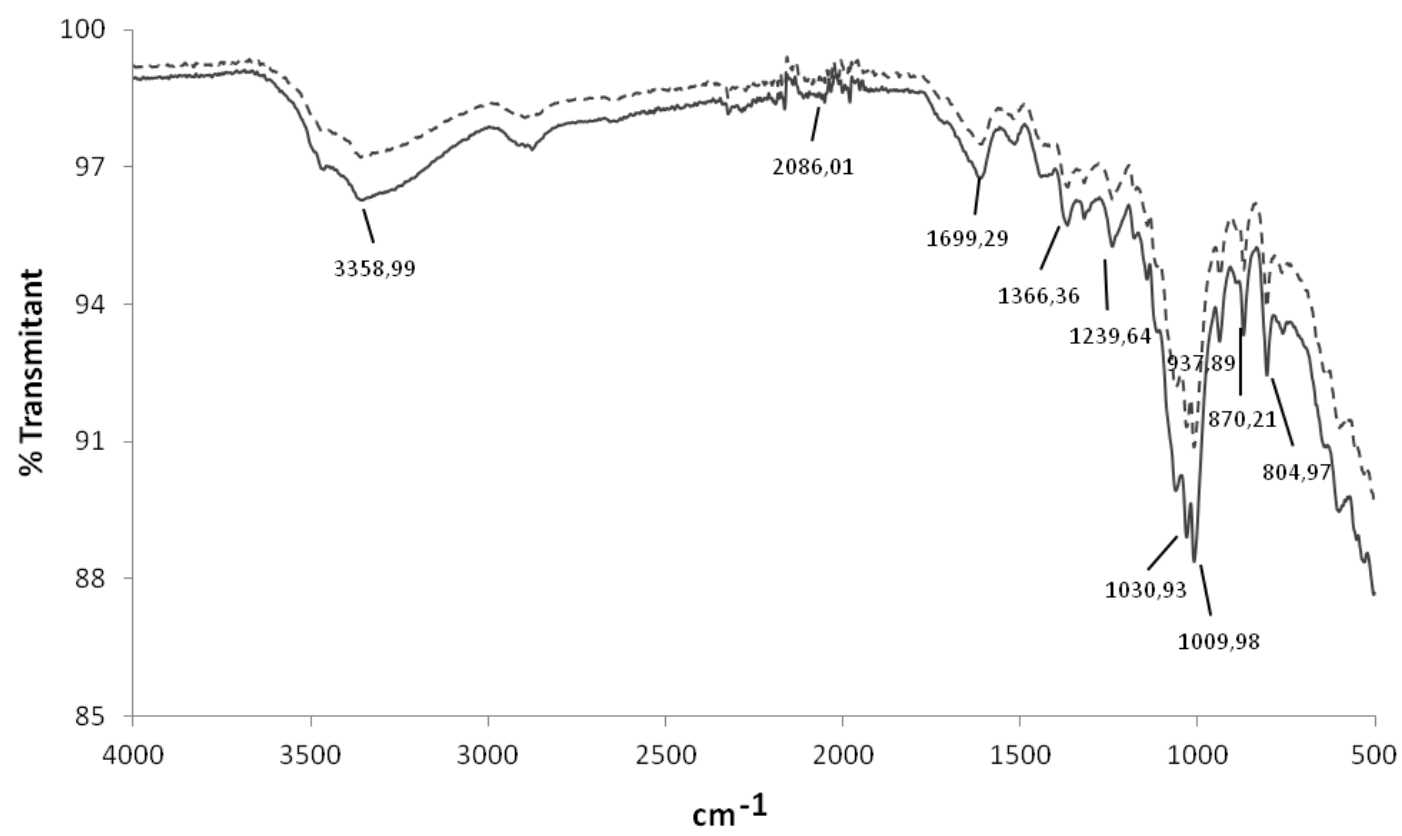

Gambar 2. Spektrum FTIR dari Biji Buah Bisbul Sebelum ( - ) dan Setelah ( - - ) Penyerapan Ion Logam $\mathrm{Cr}(\mathrm{III})$

Tabel 1. Kandungan Unsur-unsur Adsorben Biji Buah Bisbul

\begin{tabular}{lllll}
\hline Unsur & \multicolumn{1}{l}{ Biji bisbul sebelum diaktivasi } & \multicolumn{2}{l}{ Biji bisbul sebelum diaktivasi } \\
\hline & wt.\% & at.\% & wt.\% & at.\% \\
C & 75,12 & 80,09 & 74,09 & 80,03 \\
O & 24,88 & 19,90 & 24,05 & 19,51 \\
$\mathrm{Cr}$ & - & - & 1,8 & 0,04 \\
\hline
\end{tabular}



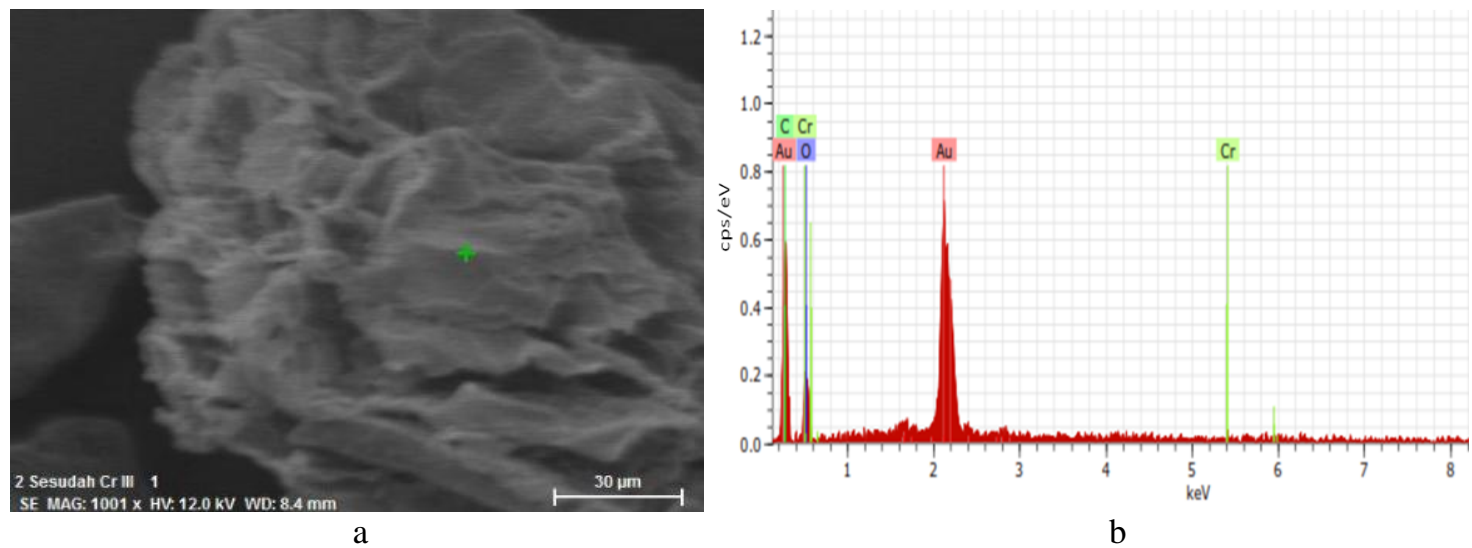

Gambar 3. (a) FE-SEM dari Biji Buah Bisbul Setelah Menyerap Ion Logam Cr(III) pada Perbesaran $1000 \times$ dan (b) Spektrum EDX pada posisi (+)

\section{SEM-EDX}

Biosorben yang telah diaktivasi dengan asam nitrat memiliki permukaan yang berpori berdasarkan hasil pengujian dengan SEM perbesaran 1000x seperti pada Gambar 3a. Pori-pori yang dihasilkan berukuran beragam. Banyaknya pori-pori yang dihasilkan ini menandakan bahwa proses aktivasi yang dilakukan adalah efektif, karena mampu membentuk pori. Puncak-puncak pada grafik memperlihatkan unsur-unsur yang ada pada adsorben yaitu adanya unsur $\mathrm{Cr}$ yang terserap pada adsrben setelah dilakukan kontak dengan larutan $\mathrm{Cr}(\mathrm{VI})$. Tidak hanya $\mathrm{Cr}$, atom lain seperti $\mathrm{C}$ dan Oksigen juga terdapat pada adsorben.

\section{Pengaruh pH}

Pengaruh $\mathrm{pH}$ dalam penyerapan ion logam $\mathrm{Cr}(\mathrm{III})$ ditunjukkan pada Gambar 4. Nilai $\mathrm{pH} 5,5$ merupakan nilai efisiensi penyerapan maksimum oleh biosorben biji buah bisbul sebesar 83,52\%. Efisiensi penyerapan $\mathrm{Cr}(\mathrm{III})$ meningkat dengan meningkatnya $\mathrm{pH}$ dalam kisaran 3,5 samapai 5,5. Ketika $\mathrm{pH}$ awal disesuaikan lebih tinggi dari 5,5, ion $\mathrm{Cr}$ (III) mengendap yang disebabkan oleh konsentrasi anion hidroksil yang lebih tinggi dalam larutan. WitekKrowiak, et al., (2011) juga melaporkan bahwa serapan logam meningkat dengan meningkatnya $\mathrm{pH}$ larutan. Ketika $\mathrm{pH}$ menurun, konsentrasi proton meningkat dan terjadi persaingan dalam mengikat permukaan biosorben oleh ion $\mathrm{H}+$ dan ion logam. Sisi aktif terprotonasi tidak mampu mengikat ion logam pengikat, yang menyebabkan ion bebas tersisa dalam larutan.

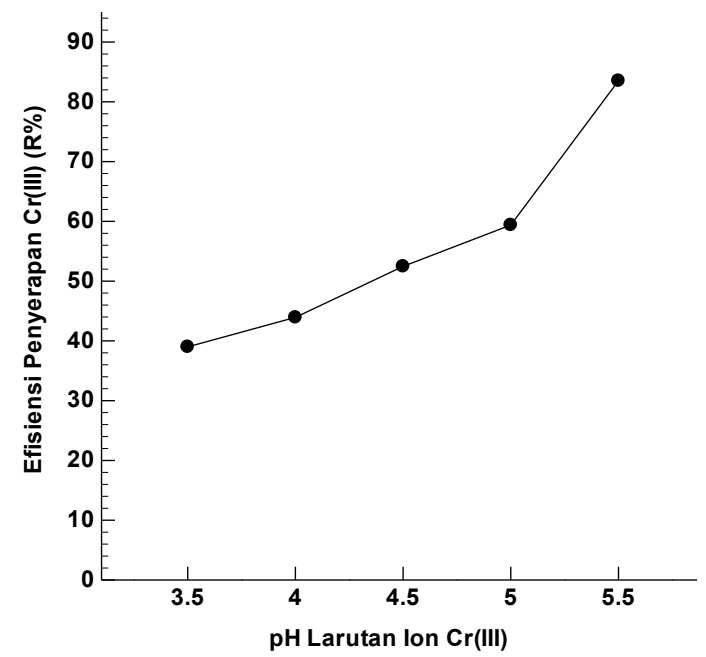

Gambar 4. Pengaruh $\mathrm{pH}$ larutan Ion $\mathrm{Cr}$ (III) terhadap efisiensi Penyerapan Cr(III)

\section{Pengaruh Waktu Kontak}

Penentuan waktu kontak optimum dibutuhkan biosorben dengan ion logam untuk berinteraksi. Pengarug waktu kontak terhadap efisiensi penyerapan ditunjukkan pada Gambar 5. Efisiensi penyerapan ion logam $\mathrm{Cr}(\mathrm{III})$ meningkat dengan semakin lama waktu kontak dengan biosorben. Hasilnya menunjukkan bahwa jumlah ion logam $\mathrm{Cr}(\mathrm{III})$ yang teradsorbsi maksimum dicapai dalam 60 menit sebesar 76,07\%. Waktu kontak dipertahankan selama 60 menit untuk memastikan bahwa kesetimbangan sepenuhnya tercapai (Rezaei, 2016). 


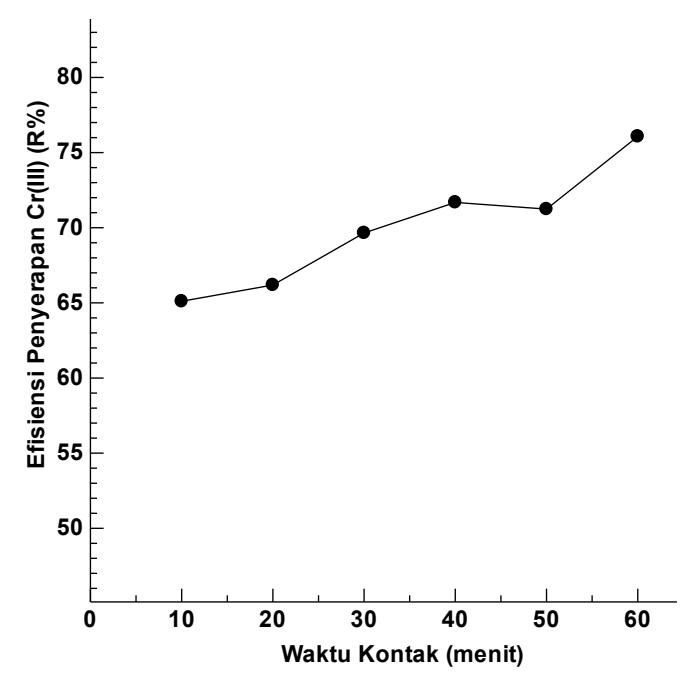

Gambar 5. Pengaruh Waktu Kontak terhadap Efisiensi Penyerapan Ion Logam Cr(III)

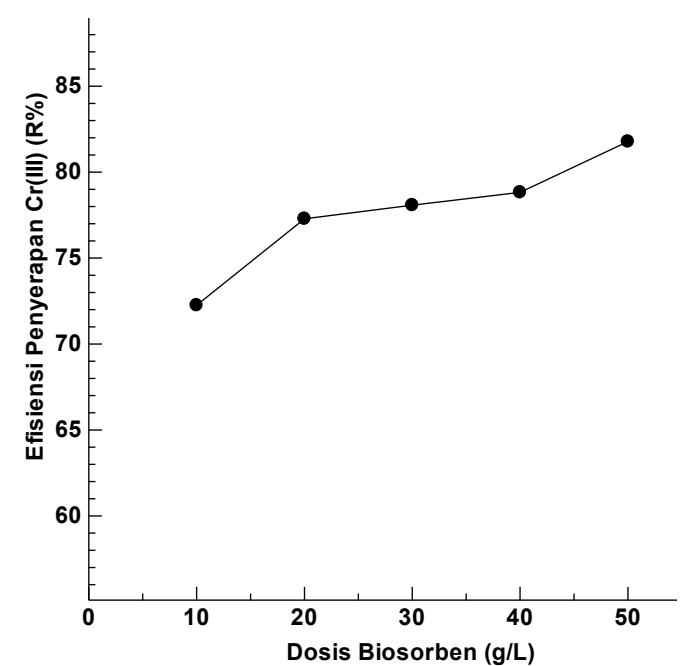

Gambar 6. Pengaruh Dosis Biosorben terhadap Efisiensi Penyerapan Cr(III)

\section{Pengaruh Dosis Biosorben}

Jumlah sisi aktif yang tersedia untuk biosorpsi tergantung pada jumlah biosorbennya (Witek-Krowiak, et al., 2011). Dengan bertambahnya jumlah dosis biosorben yang digunakan maka semakin tinggi penyerapan ion logam $\mathrm{Cr}(\mathrm{III})$ yang dapat dilihat pada Gambar 6. Penyerapan ion logam $\mathrm{Cr}(\mathrm{III})$ mencapai $81,78 \%$ pada jumlah dosis biosorben $50 \mathrm{~g} / \mathrm{L}$. Dosis biosorben yang dinaikkan menyebabkan bertambahnya area permukaan dan jumlah sisi pengikatan pada biosorben.

\section{Isoterm Biosorpsi}

Isoterm biosorpsi menggambarkan hubungan antara massa ion logam $\mathrm{Cr}$ (III) teradsorpsi per massa biosorben dan konsentrasi ion logam $\mathrm{Cr}$ (III) dalam larutan. Isoterm biosorpsi dikarakterisasi menggunakan tiga model isoterm yang telah dipilih, yaitu model Langmuir (Gambar 7.), Freundlich (Gambar 8.) dan Temkin (Gambar 9.). Data percobaan perbandingan antara tiga model isoterm yang menggambarkan kesetimbangan biosorpsi tersaji pada Tabel 1.

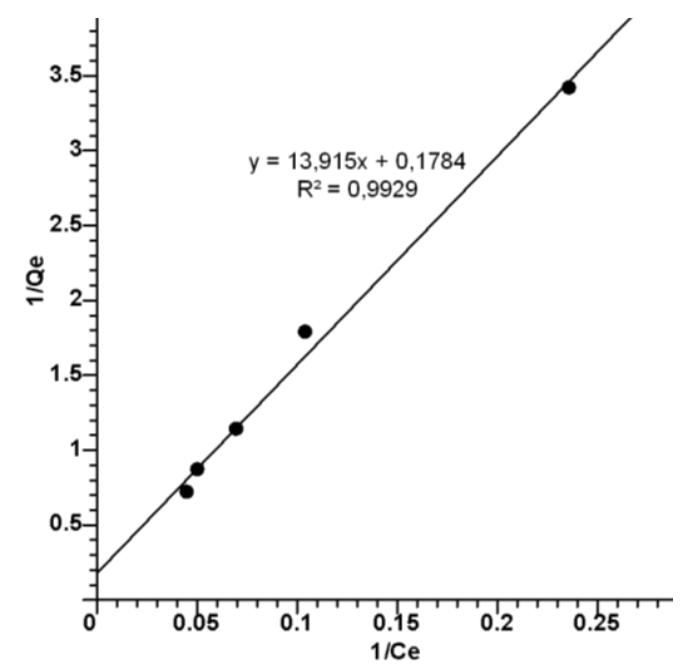

Gambar 7. Isoterm Biosorpsi Langmuir ( $\mathrm{pH} 5,5$ dan dosis biosorben $50 \mathrm{~g} / \mathrm{L}$ )

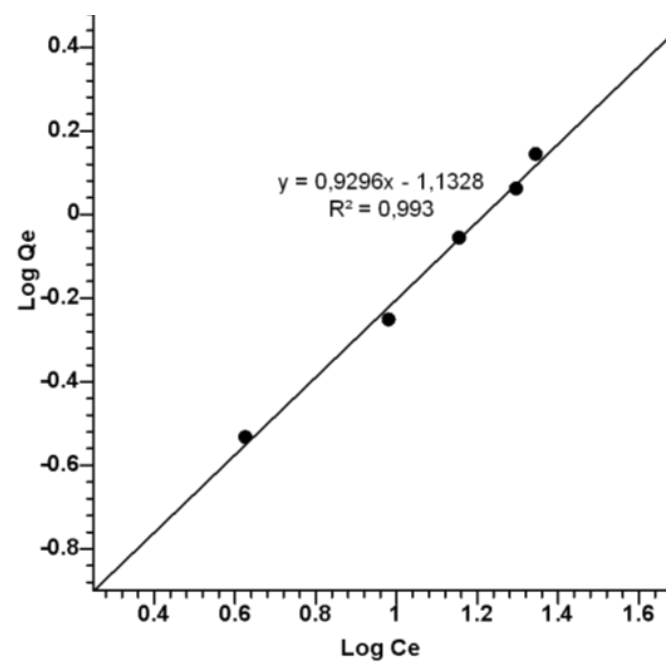

Gambar 8. Isoterm Biosorpsi Freundlich ( $\mathrm{pH} 5,5$ dan dosis biosorben $50 \mathrm{~g} / \mathrm{L}$ ) 


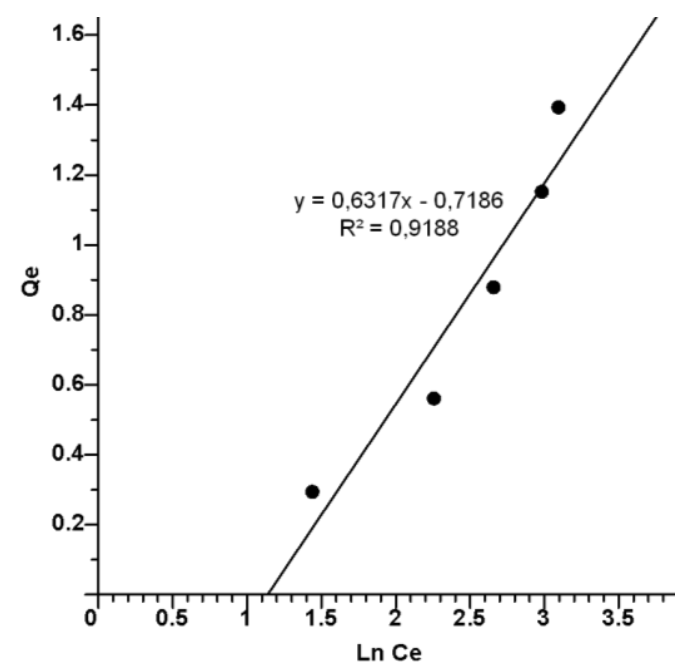

Gambar 9. Isoterm Biosorpsi Temkin ( $\mathrm{pH} 5,5$ dan dosis biosorben $50 \mathrm{~g} / \mathrm{L}$ )

Model isoterm Langmuir dan Freundlich mempunyai nilai koefisien korelasi yang tinggi mencapai 0,99. Sedangkan model isoterm Temkin, nilai koefisien korelasinya adalah 0,91. Model isoterm Langmuir dan Freundlich sangat cocok untuk menggambarkan sistem adsorpsi biji buah bisbul dengan menentukan parameter kesetimbangannya.

Nilai kapasitas penyerapan maksimum $\left(\mathrm{Q}_{\mathrm{m}}\right)$ dan konstanta Langmuir $\left(\mathrm{K}_{L}\right)$ dihitung menggunakan regresi linier. Nilai $Q_{m}$ ion logam $\mathrm{Cr}$ (III) sebesar 5,5928 $\mathrm{mg} / \mathrm{g}$, dan nilai $\mathrm{K}_{L} 0,0128 \mathrm{~L} / \mathrm{mg}$. Konstanta Freundlich (Kf) mempunyai nilai 0,3221 $\mathrm{L} / \mathrm{mg}$ dengan nilai $\mathrm{n}$ diantara $0-10$, menunjukkan adsorpsi yang relatif kuat dari ion-ion logam $\mathrm{Cr}$ (III) ke permukaan biji buah bisbul.

\section{KESIMPULAN}

Biji buah bisbul merupakan biosorben potensial yang ramah lingkungan untuk menyerap logam berat. Efisiensi penyerapan biji buah bisbul diperiksa dalam menyerap ion logam $\mathrm{Cr}$ (III) dalam larutan. Beberapa parameter seperti, pH larutan, waktu kontak dan dosis biosorben mempengaruhi hasil biosorpsi.

Tiga model isoterm adsorpsi digunakan untuk menggambarkan kesetimbangan biosorpsi ion logam $\mathrm{Cr}$ (III) ke permukaan biji buah bisbul. Penelitian ini menunjukkan kondisi optimum penyerapan pada $\mathrm{pH}$ 5,5, waktu kontak 1 jam, dan dosis biosorben $50 \mathrm{~g} / \mathrm{L}$. Kapasitas penyerapan maksimum didapat dengan menggunakan model isoterm Langmuir yaitu $5,5928 \mathrm{mg} / \mathrm{g}$. Efisiensi penyerapan ion logam $\mathrm{Cr}$ (III) mencapai $81,78 \%$. Hasil yang diperoleh menunjukkan bahwa biji buah bisbul adalah biosorben yang efisien dalam menyerap ion logam $\mathrm{Cr}(\mathrm{III})$.

\section{UCAPAN TERIMAKASIH}

Penelitian ini didanai dengan program Penelitian Kompetitif Nasional dengan Skim Penelitian Dosen Pemula (PDP) tahun pelaksanaan 2018 sesuai kontrak nomor : 0802/K4/KM/2018 tanggal 12 Februari 2018 oleh Kementrian Riset, Teknologi dan Pendidikan Tinggi Republik Indonesia.

Tabel 2. Parameter-parameter Model Isoterm dari Ion Logam Cr(III)

\begin{tabular}{ccc}
\hline Model Isoterm & Parameter & $\mathrm{Cr}(\mathrm{III})$ \\
\hline Langmuir & $\mathrm{Q}_{\max }(\mathrm{mg} / \mathrm{g})$ & 5,5928 \\
& $\mathrm{~K}_{L}(\mathrm{~L} / \mathrm{mg})$ & 0,0128 \\
\multirow{3}{*}{ Freundlich } & $\mathrm{R}^{2}$ & 0,9929 \\
& $\mathrm{~K}_{f}(\mathrm{~L} / \mathrm{mg})$ & 0,3221 \\
& $n$ & 1,0745 \\
Temkin & $\mathrm{R}^{2}$ & 0,993 \\
& $A$ & 0,7186 \\
& $B$ & 0,6317 \\
\end{tabular}




\section{DAFTAR PUSTAKA}

Acar, O., Ozvatan, S., \& Ilim, M. (2005). Determination of cadmium, copper, iron, manganese, lead and zinc in lichens and botanic samples by electrothermal and flame atomic absorption spectrometry. Turk J. Chem, $29,335-344$.

Akter, S., Majunder, T., Karim, R., Ferdous, Z., \& Sikder, M. (2015a). AnalgesicActivities of Geodorum densiforum, Diospyros blancoi, Baccaurea ramifora and Trichosanthes dioica. Journal of Pharmacochemistry, 4, 209-2014

Akter, S., \& Sarker, A. (2015b). Antimicrobial activities of seeds of Diospyros blancoi and Baccuarea ramiflora. International Journal of Advances in Pharmacy, Biology and Chemistry, 4, 789-793.

Andrade, A. D., Rollemberg, M. C. E., \& Nobrega, J. A. (2005). Proton and metal binding capacity of the green freshwater alga Chaetophora elegans. Process. Biochem., 40 (5), 1931-1936.

Babarinde, N. A. A., Babalola, J. O., \& Sanni, S. O. (2007). Isotherm and Thermodynamic Studies of The Biosorption of Cd(II) from Solution by Maize Leaf. International Journal of Physical Sciences, 2(8), 207-211

Beolchini, F., Pennesi, C., Romagnoli, T., Totti, C., Centofanti, M., Mosca, L., \& Veglio, F. (2005). Lead biosorption by marine macrophytes: effect of macrophyte structure and $\mathrm{pH}$ on the process. Chemical Engineering Transaction, 6, 885-890.

Cheenmatchaya, A., \& Kungwankunakon, S. (2014). Preparation of Activated Carbon Derived from Rice Husk by Simple Carbonization and Chemical Activation for Using as Gasoline Adsorbent. International Journal of
Environmental Science and Development, 5, 171-175.

Cobas, M., Saronman, M. A., \& Pazos, M. (2014). Box-Behnken methodology for $\mathrm{Cr}(\mathrm{VI})$ and Leather dyes removal by an eco-friendly biosobent: F. vesiculosus. Bioresource Technology, 1-9.

Dyer, A., Tangkawanit, S., \& Rangsriwatananon, K. (2004). Exchange diffusion of $\mathrm{Cu}^{2+}, \mathrm{Ni}^{2+}, \mathrm{Pb}^{2+}$ and $\mathrm{Zn}^{2+}$ into analcime synthesized from perlite. Microporous and Mesoporous Materials, 75, 273-279.

Gandhi, N., Sirisha, D., \& Sekhar, K. B. C. (2013). Adsorption Studies of Chromium y Using Low Cost Adsorbent. Our Nature, 11, 11-16.

Gupta, V. K., Pathania, D., Agarwal, S., \& Sharma, S. (2012). Removal of Cr(VI) onto Ficus carica biosorben from water. Environ Sci Pollut Res. 20(4), 26322644.

Howlader, M. S. I., Rahman, M. M., Khalipa, A. B. R., Ahmed, F., \& Rahman, M. M. (2012). Antioxidant and Antidiarrheal Potentiality of Diospyros blancoi. International Journal of Pharmacology, 5, 403-409.

Kanawade, S. M., \& Gaikwad, R. W. (2011). Removal of Methylene Blue from Effluent by Using Activated Carbon and Water Hyacinth as Adsorbent. International Journal of Chemical Engineering and Application, 2, 317-319.

Kumar, R., Arya, D. K., Singh, N., \& Vats, H. K. (2017). Removal Cr(VI) Using Low Cost Activated Carbon Developed By Agricultural Waaste. Journal of Applied Chemistry, 10, 76-79.

Linda, B., Lim, L., Priyantha, N., Tennakoon, D. T. B., \& Dahri, M. K. (2012). Biosorption of cadmium(II) and copper(II) ions from aqueous solution 
by core of Artocarpus odoratissimus.

Environ Sci Pollut Res,. 19, 3250-3256.

Nagase, H., Inthorn, D., Oda, A., Nishimura, J., Kajiwara, Y., Park, M., Hirat, K., \& Miyamoto, K. (2005). Improvement of selective removal of heavy metals in cyanobacteria by $\mathrm{NaOH}$ treatment., Journal of Bioscience and Bioengineering, 99(4): 372-377.

Naiya, T. K., Singha, B., \& Das, S. K. (2011). FTIR Study forthe Cr(VI Removal from Aqueous Solution Using Rice Waste. International Conference on Chemistry and Chemical Process, 10, 114-119

Palar, H. (1994). Pencemaran dan Toksikologi Logam Berat. Jakarta: Rineka Cipta.

Podstawczyk, D., Witek-Krowiak, A., Chojnacka, K., \& Sadowski, Z. (2014). Biosorption of Malachite Green by eggshells: mechanism Identification and Process Optimization. Biorsource Technology. 160, 161-165.

Prakash, N., Sudha, P. N., \& Renganathan, N. G.. (2011). Copper and cadmium removal from synthetic industrial wastewater using chitosan and nylon 6 . Environ Sci Pollut Res. 19, 2930-2941.

Prakash, N., Latha, S., Sudha, P. N., \& Renganathan, N. G. (2012). Influence of clay on the adsorption of heavy metals like copper and cadmium on chitosan. Environ Sci Pollut Res. 20(2): 925-938.

Preetha, B., \& Virutaghiri, T. (2005). Biosorption of zinc (II) by Rhizopus arrhizus: equilibrium and kinetic modelling, African Journal of Biotechnology. 4 (6): 506-508.

Ranjan, D., P. Srivastava, M. Talat, S. H. Hasan. (2009). Biosorption of $\mathrm{Cr}(\mathrm{VI})$ from Water Using Biomass of Aeromonas hydrophila: Central Composite Design for Optimization of
Process Variables. Appl Biochem Biotechnol. 158, 524-539.

Rezaei, H. (2016). Biosorption of chromium by using Spirulina sp. Arabian Journal of Chemistry. 9, 846-853.

Shendkar, C. D., Torane, R. C., Mundhe, K. S., Lavate, S. M., Pawar, A. B., \& Deshpande, N. R. (2013). Characterization and Application of Activated Carbon Prepared From Fom Waste Weed. International Journal of Pharmacy and Pharmaceutical Sciences. 5, 527-529.

Singha, B, Naiya, T. K., Bhattacharya, A. K., \& Das, S. K. (2011). Cr(VI) Ions Removal from Aqueous Solution using Natural Adsorbents-FTIR Studies. Journal of Environmental Protection. 2, 729-735

Stuart, B. (2004). Infrared Spectroscopy Foundamentals and Aplications. John Wiley \& Sons, Ltd. New York.

Vankar, P. S., Sarswat, R., \& Sahu, R. (2012). Biosorption of Zinc Ions from Aqueous Solutions onto Natural Dye Waste of Hibiscus rosa sinensis: Thermodynamic and Kinetic Studies. Environmental Progress \& Sustainable Energy. 31 (1), 89-99.

Vieira, H.S.F.R., \& Volesky, B. (2000). Biosorption: a solution to pollution?. Internatl. Microbiol. 3, 17-24.

Witek-Krowiak, A., Szafran, R. G., \& Modelski, S. (2011). Biosorption of heavy metals from aqueous solutions onto peanut shell as a low-cost biosorbent. Desalination. 265, 126-134

Wanja, N. E., Murungi, J., Wanjau, R., \& Hassanali, A. (2015). Application of Chemically modified avocado seed for removal of Copper (II), Lead(II), and Cadmium (II) ions from aqueous solutions. International Journal of Research in Engineerng and Applied Science (IJREAS). 6, 1-15 
Yalcin, S., Sezer, S., \& Apak, R. (2012). Characterization and lead(II), cadmium(II), nikel(II) biosorption of dried marine brown macro algae Cytoseria barbata. Environ Sci Pollut Res. 19, 3118-3125.

Zein, R., Suhaili, R., Earnestly, F., Indrawati, \& Munaf, E. (2010). Removal of $\mathrm{Pb}(\mathrm{II}), \mathrm{Cd}(\mathrm{II})$ and from aqueous solution using Garcinia mangostana L. fruit shell. Journal of Hazardous Materials. 181, 52-56.

Zein, R., Arrisujaya, D., Hidayat, Elfia, M., Nazarudin, N., \& Munaf, E. (2014). Sugar Palm Arenga pinnata Merr (Magnollophyta) fruit shell as biomaterial to remove $\mathrm{Cr}(\mathrm{III}), \mathrm{Cr}(\mathrm{VI})$, $\mathrm{Cd}(\mathrm{II})$ and $\mathrm{Zn}$ (II) from aqueous solution. Journal of Water Supply. 63, 553-559. 